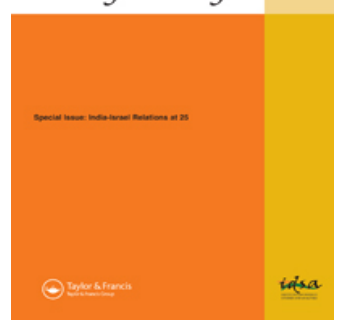

\title{
Assessing US Influence over India-Israel Relations: A Difficult Equation to Balance?
}

\section{Nicolas Blarel}

To cite this article: Nicolas Blarel (2017) Assessing US Influence over India-Israel Relations: A Difficult Equation to Balance?, Strategic Analysis, 41:4, 384-400, DOI: 10.1080/09700161.2017.1330437

To link to this article: https://doi.org/10.1080/09700161.2017.1330437

(c) 2017 The Author(s). Published by Informa
UK Limited, trading as Taylor \& Francis
Group

Submit your article to this journal $₫$

Џll Article views: 489

View Crossmark data $\asymp$ 


\title{
Assessing US Influence over India-Israel Relations: A Difficult Equation to Balance?
}

\author{
Nicolas Blarel
}

\begin{abstract}
As India's Israel policy evolved over time, the US involvement in this bilateral relationship has been constant, albeit neither consistent nor direct. Breaking with traditional state-centric approaches, this article focuses on the key role played in shaping the nature of India-Israel ties by non-state and sub-state actors such as specific political personalities, for example Congressmen Emmanuel Celler in the 1940s and Stephen Solarz in the 1980s, as well as of pro-Israel interest groups based in the US, like the Anti-Defamation League (ADL) and the American Jewish Committee (AJC). The article shows that the US factor in India-Israel relations has evolved over time depending on the personalities, political constellations in power in India and regional developments in West Asia. Finally, while India, Israel and US interests seem to have converged at some crucial junctures, the article argues that their policies and strategies have rarely aligned over the long term.
\end{abstract}

$\mathbf{I}_{\mathrm{s}}^{\mathrm{n}}$ $\mathrm{n}$ the summer of 1947, while many observers focused on the partition of the Subcontinent, one of India's first major forays into diplomatic and international politics was unfolding in the newly created United Nations (UN) in New York. On the initiative of Prime Minister Jawaharlal Nehru, India lobbied to become a member of the UN Special Committee on Palestine (UNSCOP). While this might have seemed like a logical step for a newly independent India which aimed at signalling its ambition to become a significant player in world politics, especially in the new global institutional architecture emerging out of the post-World War II order, it also embarked more or less knowingly into what would become one of its first major disputes with the US. This lesser known historical debate which took place between April and September 1947 at the UN structured a major bilateral disagreement between India and the US for decades to come.

As India's Israel policy evolved over time, moving from India's initial opposition to the partition of Palestine in September 1947 to the recognition of the state of Israel in September 1950, and then from the decision to defer the establishment of diplomatic relations for 42 years to the post-normalisation development of strong bilateral trade and military ties since $1992,{ }^{1}$ US involvement in this bilateral relationship has been constant, albeit neither consistent nor direct.

Various strands of scholarship have, for instance, insisted on the long-term influence of the US on India's policy of non-relationship with Israel. Some noted that leaders like Nehru had regarded Israel as a state that had been set up with the support of imperialist powers, and especially from the US. ${ }^{2}$ These notably point to

Nicolas Blarel is Assistant Professor, at the Institute of Political Science, Leiden University, The Netherlands. 
Prime Minister Nehru's criticism of the US government's involvement in the Palestine debate at the UN in 1947. Others argued that the prolonged estrangement between India and Israel until 1992 could be explained by Cold War divisions. ${ }^{3}$ India and Israel were two countries considered to be more or less integrated in the two rival Cold War blocs, thus inhibiting any rapprochement.

However, both individual- and international-level arguments fail to understand how the US influence on India's Israel policy has varied over time, depending on the leadership in power in New Delhi and Washington, the regional developments in West Asia and the wax and wane of international factors such as the Cold War on both subcontinental and West Asian politics. In addition, this article breaks with traditional state-centric approaches which overlook much of the transnational activity that has happened between the Indian, Israeli and US policy systems and societies. For instance, it does not make the argument that the US directly and consistently pressured New Delhi to improve its ties with Israel. In fact, this issue was not a direct concern of US foreign policy towards South Asia and West Asia until the late 1980s. State-centric arguments have therefore neglected the indirect but decisive influence and transnational networks of particular historical characters, which were not in the executive branch or the foreign policy bureaucracy, such as US Congressmen Emmanuel Celler in the 1940s or Stephen Solarz in the 1980s, as well as of influential Jewish interest groups in the US political system, such as the Anti-Defamation League (ADL) and the American Jewish Committee (AJC).

For instance, while initially in disagreement with US policymakers over the conditions leading to the creation of the state of Israel, Nehru did maintain channels of communication with Israeli leadership which were facilitated through the mediation of American actors, albeit not part of government. This sustained dialogue can explain India's eventual recognition of Israel in 1950. In 1956, both India and the US criticised Israel's intervention alongside France and the UK during the Suez crisis. After 1991, while the end of the Cold War and US lobbying for a change in India's approach to Israel towards the establishment of diplomatic relations in January 1992 were important factors, the story of US influence is of a more indirect and incremental nature as it can be dated back and in the form of mediation of American Jewish organisations to the mid-1980s. ${ }^{4}$ Finally, while the US has initially encouraged the development of defence ties between India and Israel, its defence industries find themselves today in direct competition with Israeli firms.

As a result, it is important to evaluate how interdependent were India-US and India-Israel ties since 1947, but also to assess when and how American influence, both direct and perceived, acted as a constraining or enabling influence over the development of India-Israeli relations. The remainder of the article is organised as follows: First, I discuss the initial exchanges between Indian and Jewish nationalisms in the 1930s which were facilitated by the mediation of certain US actors. Second, I look at the US-India dispute over the creation of the state of Israel, leading all the way to the recognition of September 1950. In the third section, I explain the growing estrangement between the Indian and American positions over the various West Asian disputes from the 1950s to the 1980s. Fourth, I describe how US domestic politics, and especially certain US politicians and interest groups, encouraged the rapprochement between India and Israel and the normalisation of bilateral ties in January 1992. Subsequently, I evaluate in the fifth section the evolving role of US support for defence ties between India and Israel but also at possible hurdles as both American and Israeli defence industries 
increasingly compete for some markets. Finally, I conclude and suggest some possible future trends in the India-Israel-US equation.

\section{Pre-1947: Dialogue between Indian and Jewish nationalism through American mediation}

India's Israel policy was formed in the pre-independence period, and most especially when the Indian National Congress (INC) made its first statements on the IsraelPalestine issue in the $1920 \mathrm{~s}$ and $1930 \mathrm{~s} .{ }^{5}$ As a result, even before independence, there were regular interactions between members of the INC with advocates for the creation of the state of Israel, many of whom were US-based representatives of the Jewish agency.

Because of the mainly European and North American origins of the immigration movement to Palestine in the 1930s (mostly from Britain, Eastern Europe and the US), Indian nationalists initially identified Zionism with its countries of origin. ${ }^{6}$ The fact that the Zionist movement drew most of its financial and political support from European and US sources initially led the INC leaders to consider Zionism as a movement that was directly under the influence of British and American interests. In parallel, since the major priorities for the Zionist movement were arms procurement, fund raising and facilitating Jewish immigration in Palestine, the INC was not considered a priority in its diplomatic efforts. The Zionist movement also avoided identifying itself with other nationalist movements in Asia and made a tactical choice to concentrate its diplomatic attention on British and American material and political support. $^{7}$

However, US-based Zionists regularly engaged with Indian nationalist leaders. By the early 1930s, the Jewish agency attempted to establish contacts with Gandhi and Nehru whom they considered to be influential personalities both in India and internationally. ${ }^{8}$ By the early 1930s, the Jewish Agency also realised that it needed to counter the anti-Zionist message circulated in India through the efforts of Mufti alHussayni. For instance, Hayim Greenberg, editor of the US-based Jewish Frontier newspaper, expressed his concerns about anti-Zionist sentiments spreading among Indian Muslim communities in a letter he sent to Gandhi in $1937 .^{9}$

Repeated efforts from American Zionists to get Gandhi to publicly express himself about the Palestine issue paid off in 1938. However, his statements on Palestine belonging to the Arabs and his condemnation of Zionist collaboration with imperialist Britain in his famous 1938 Harijan article revealed the difficulties of the Jewish Agency's efforts in convincing the Indian nationalist leader of their cause. Americans like Hayim Greenberg directly accused Gandhi of being biased and unfair towards the Jews. He noted that Gandhi had overlooked the imperative existential need for a Jewish homeland. Gandhi responded to this accusation in another column in Harijan and even reproduced an abridgement of Greenberg's letter, pointing out that he saw no reason to change his opinion. ${ }^{10}$

According to Nehru, the problem of Palestine was primarily an Arab nationalist struggle against British imperial control. By contrast, the Jewish issue was a minority religious problem that had mainly been fostered by British policies. He notably suggested a federal arrangement which would guarantee Jewish religious rights in Palestine. ${ }^{11}$ Like Gandhi, Nehru too was approached by Zionist emissaries before and after independence, who were looking for his support on the creation of a Jewish state. 
After World War II, Gandhi's position seemed to have evolved. Although he condemned the persecution of the Jews in Europe in strong terms, he insisted that restoring Palestine to the Jews, partly or wholly, as their national home would be a crime against humanity, as well as against the Muslims. ${ }^{12}$ In spite of this statement, Gandhi met the American Unitarian minister and pacifist John Haynes, who had been sent by New York Rabbi and noted Zionist Stephen Wise. ${ }^{13}$ Gandhi also met in 1946 the American journalist Louis Fischer to whom he conceded that the Jews had a 'prior claim' to Palestine. However, in a later article in Harijan in July 1946, Gandhi clarified his position: he argued the Jews had been 'wronged by the world' but he also criticised their reliance on American and British help as well as on terrorist methods. $^{14}$

These various statements demonstrate that Gandhi and Nehru did not have a static opinion of the Palestine issue but instead a nuanced and evolving perception of the situation, to some part informed by their meetings and discussions with American Zionists and members of the Jewish Agency. Gandhi died a few months before the creation of Israel, and did not therefore have any direct impact on India's Israel policy. By contrast, Nehru had a key foreign policy-making role after independence as he held both the positions of prime minister and minister of external affairs. His early contacts with American Zionists would prove important in the early postindependence years.

\section{7-1950: the creation of Israel as a first disagreement between India and the US}

From April to September 1947, India and the US faced their first major diplomatic dispute as the Palestine question was presented by the British to the UN General Assembly (UNGA). Nehru supported the British proposal for the UN to deal with the Palestine question and nominated Asaf Ali, India's first ambassador to the US, as its first representative to the Special UNGA Session on Palestine. Ali was given very specific guidelines, notably to support a termination of the Mandate and ensure that India would be part of any fact-finding committee on Palestine. Ali was also warned not to commit the government to any position without any prior approval from New Delhi, and to avoid raising issues which might 'affect' India's relations with other countries. ${ }^{15}$ The instructions showed that India's position was not fixed and remained open to debate. Furthermore, Nehru was conscious that India's decisions would be closely scrutinised by its international partners, especially the US.

At the UN, Ali actively argued against the interference and influence of great powers, such as the US and UK, on the Palestine issue. After an intense debate which lasted until May 15, 1947, it was decided that the five major powers (permanent members of the UN Security Council [UNSC]) would be excluded from membership of the specialised committee created to study the Palestine issue. Following Nehru's instructions, Ali lobbied for India to be a member of the UNSCOP. However, India had problems integrating the initial list of neutral members of the Committee as suggested by the US Ambassador to the UN, Warren Austin.

Nehru was disappointed with Ali's performance, which contradicted his instructions to avoid controversy. ${ }^{16}$ Ali notably attempted to include in the Agenda of the Special Palestine Committee a proposal which demanded the immediate termination of the Mandate and the proclamation of the independence of Palestine. In addition, Ali invited the Arab Higher Committee, represented by Mufti Hussayni, to talk before the 
Special Committee. However, he also supported inviting the Jewish Agency to testify. Ali's overt pro-Arab position led him to clash with other representatives on the Committee. ${ }^{17}$ Nehru was therefore concerned that Ali's stance could affect relations with India's Western partners and cautioned him against raising divisive issues such as the Arab proposal for immediate independence. Nehru mentioned that he had heard 'adverse comments' following Ali's statements and he recommended making 'fewer commitments' on the issue. ${ }^{18}$ While Nehru wanted India to maintain its sympathy for Arab grievances, he also preferred maintaining a cautious and open-ended policy to not upset ties with the US.

Finally, the UNGA decided to appoint a more representative UNSCOP. Membership was extended to two other members from the South Pacific and Asian regions, which were underrepresented in the initial nine-member committee. The expansion opened the door for India. After the initial reactions to Ali's statements, it became a priority for Nehru to reframe India's position as a more balanced observer of the dispute. One first move was to nominate Sir Abdur Rahman as India's representative to the UNSCOP. Nehru asked Rahman to support a federal solution which had to gain Arab approval. However, given the strong divisions on this issue and the uncertain outcome of the deliberations, Nehru also suggested to keep a 'vague' position and to remain 'friendly' to both parties. ${ }^{19}$ Nehru did not want Rahman to make the same mistakes as Ali and to rhetorically commit India in one direction.

However, significant disagreements emerged between Rahman and Nehru. Rahman, for instance, expressed doubts about the continuing legal status of India in the UN structure following the partition of the Subcontinent. Consequently, Rahman defended India's federal solution at the UNSCOP, but also offered a dissenting note on August 14, 1947. Rahman agreed with Nehru's position that partition was not a viable solution as it would not lead to a lasting peace plan between Arabs and Jews. ${ }^{20}$ However, in his personal note, he rejected the federal solution which he judged equally impractical as it was opposed by all parties. ${ }^{21}$ Ultimately, Rahman personally supported a unitary state where a clear Muslim Arab majority (three-fourths) had a right to self-determination. A partition scheme would, in the view of Rahman, be opposed to the principle of self-determination. ${ }^{22}$ However, Rahman also argued that religious, cultural, linguistic and educational rights should be defended by the constitution of a new Palestinian state, and that there should be proportional quotas for Jewish participation in government and other public offices.

The Jewish Agency closely monitored these disputes between New Delhi and its representative given its apprehensions that Rahman would support the Arab case within the UNSCOP. There were various efforts to inform Nehru of Rahman's perceived bias. American Congressman and Zionist Emmanuel Celler notably played an important role by directly expressing his concerns about Rahman in a cable he sent to Nehru. Celler was popular in India because of his support to the Indian struggle for independence in the American Congress. In the 1940s, Celler also became an advocate of more flexible US immigration laws to help Jewish refugees fleeing the Holocaust. Celler had also been instrumental in facilitating the invitation of a Jewish delegation to the New Delhi Conference of the Asian Relations Organisation which took place in March-April 1947. India had initially invited 32 delegations, including a delegation from Palestine. There was a strong opposition within the INC against inviting a Jewish delegation. ${ }^{23}$ However, pressure from both Sarojini Naidu and especially Nehru's sister and India's representative to the UN, Vijaya Lakshmi 
Pandit, who had discussed the issue with Celler in Washington, proved decisive. ${ }^{24}$ Following the conference, the Jewish delegation highlighted the importance of seeking the assistance of US politicians who had supported both Indian nationalism and Zionism, such as Congressman Celler. Consequently, in his response to Celler, Nehru explained he had given instructions to Rahman that highlighted the quasi-judicial character of the inquiry and confirmed India's impartial stance. ${ }^{25}$

In October 1947, as the UNGA vote on the Palestine issue was nearing, Celler attempted to influence the Indian voting by directly appealing to Pandit, who was the Indian representative to the UNGA. The US supported partition, while India supported a federal plan. Pandit had her personal reservations with Nehru's position. ${ }^{26}$ She notably had warned the Ministry of External Affairs (MEA) through a letter on October 8, 1947 that India's federal plan had little support as both contending parties, including the Arabs, rejected it. ${ }^{27}$ In addition, a report was reportedly sent to Ben-Gurion stressing the fact there had been a debate within the Indian delegation on the voting and that Pandit had suggested to Nehru to abstain on the partition plan. ${ }^{28}$

However, Celler's efforts to sway India towards a support of the partition plan proved unfruitful, as Pandit did not directly defy Nehru's instructions from New Delhi and the Indian delegation stood by its support for the federal plan on November 29, 1947. India and the US disagreed on the partition plan but also on the recognition of the state of Israel following its proclamation of independence on May 14, 1948. Although there was a debate in the Harry Truman administration, the US recognised Israel within hours of the proclamation. ${ }^{29}$ On May 17, 1948, Moshe Sharret, the minister of foreign affairs of the provisional government of Israel, sent a cable to Nehru to seek India's formal recognition of the new state of Israel. ${ }^{30}$ Eliahu Eilat (Epstein), the representative of Israel's provisional government of Israel in the US, sent another cable to the Indian chargé d'affaires in Washington. ${ }^{31}$

Since there was no official reaction from New Delhi, Israel actively used the channels of communication between Eilat and Indian diplomats in Washington and New York to push for recognition. Israeli diplomats also tried to use India's close links with the US to pressure Delhi into changing its policy. Since the US financial support at the time was considered by Indian decision-makers as necessary for the success of India's first five-year plan, diplomatic pressure (or at least a perception of such) was considered important. ${ }^{32}$ Congressman Celler was regularly invited to meetings between Israeli and Indian diplomats to help persuade the latter. ${ }^{33}$

In September 1948, after the second Arab-Israeli ceasefire was signed, India's Ambassador to the US, B. N. Rau, mentioned the possibility of recognition to his Israeli counterpart Eliahu Eilat in Washington. In a later discussion in May 1949, Pandit, now Indian Ambassador to the US, reportedly acknowledged to Eilat in Washington that the situation in Kashmir had postponed the recognition. ${ }^{34}$ In September 1949, following the acceptance of Israel as an official member of the UN, Pandit assured Eilat that India was moving towards recognition. ${ }^{35}$ In October 1949, during a visit to Washington, Nehru met with Ambassador Eilat and Congressman Celler. Nehru explained that the recognition of Israel had been delayed because of internal opposition which had to be treated carefully. Nehru did, however, concede that recognition of Israel could not be indefinitely postponed. ${ }^{36}$ In a letter to Sharett, Eilat also said that Nehru had directly discussed the impact of the 'painful' partition on the ' 30 million Indian Muslims' and that the Palestine question was a 'constant source of agitation' for this community. ${ }^{37}$ Nehru reportedly also indicated to 
Celler that it would be 'unwise' for him to recognise Israel during his stay in the US as it could be interpreted as 'American pressure'. ${ }^{38}$

In spite of these regular meetings, India deferred the recognition of the state of Israel until September 1950 and decided to indefinitely postpone the establishment of diplomatic relations. As a result, barring a few exceptions, India and the US stood at odds when it came to the Israel-Palestine dispute for the next four decades.

\section{0s-1980s: India and the US on different sides of the West Asian divides}

During three decades, India and the US stood on different sides of the sectarian and/or geopolitical disputes which divided West Asia. For some time, their interests also directly conflicted. This had an important effect on India's policy towards Israel. In the early 1950s, for instance, the US initiated an alliance, institutionalised through the Baghdad Pact of 1955, which was officially conceived to contain Soviet Expansion in West Asia and which included Pakistan. ${ }^{39}$ This alliance was perceived as directly affecting India's security interests as it permitted Pakistan to boost its military arsenal and to thereby reject any diplomatic settlement of the Kashmir dispute. In order to counter this new military alliance project, and the introduction of Cold War politics in West Asia, Nehru decided to reinforce India's relations with other Arab states such as Egypt and Syria.

As a result, at that time, Nehru was reluctant to establish diplomatic relations with Israel. India felt it was necessary to emphasise a shared outlook with Arab states on most West Asian issues, including the Israel-Palestine dispute. Beyond Egypt, other Arab states lauded India for its opposition to the Baghdad Pact and criticised Pakistan's membership. Saudi Arabia's King Saud, two years after he had visited and supported Pakistan on the Kashmir issue, expressed his disappointment that the 'Islamic State of Pakistan should accede to those who have joined hands with the Zionist Jews' by joining a 'Western Military Pact'. ${ }^{40}$ The rapprochement between India and key Arab states helped to check Pakistan's diplomatic attempts to create a coalition of Muslim Arab states and to dispel the notion that the Government of India was pro-Zionist following the recognition of Israel.

In spite of these contrasting diplomatic alignments in West Asia, India and the US agreed to jointly condemn Israeli policies during the Suez crisis. In July 1956, the Egyptian President Gamal Abdel Nasser decided to nationalise the Suez Canal. This sudden and drastic move was the result of a protracted political dispute which had developed over a proposal between Egypt, the US and UK for the funding for the construction of the Aswan High Dam. As the Suez Canal was a strategic trade link which had remained under British control after Egyptian independence, the decision to nationalise was considered a move that directly defied European powers which had important stakes in the Canal.

India's initial reaction was to support Nasser's decision. Nehru argued in August that the Egyptian decision complied with the terms of sovereign Egypt's laws. ${ }^{41}$ However, looking to also support international legal principles, Nehru referred to the 'international character' of the Suez waterway according to the Anglo-Egyptian Agreement of 1954. Nehru equally regretted the 'suddenness' of the decision and of its implementation, which directly affected European economic interests. The Indian argument was that Egypt was competent to nationalise the Suez Canal but should have done so in 'the normal way of international expropriation'. ${ }^{42}$ Nehru therefore 
deplored the lack of consultation through UN-led mechanisms between the UK and Egypt on this matter.

India's position during the Suez crisis was not only shaped by moral and legal consideration but also by its own national self-interest. Nehru was concerned by the long-term consequences linked to the closing of the Canal to international circulation. India was not a 'disinterested party' but a 'principal user of this waterway' whose 'economic life and development' was directly affected. ${ }^{43}$ Consequently, India advised all the involved countries to abandon threats, violence and unilateral acts in order to avert an escalation to a crippling conflict in the region. ${ }^{44}$ In spite of these specific national interests, Nehru directly corresponded with US President Dwight Eisenhower and British Prime Minister Anthony Eden concerning a conference of the canal users to be held in London. Nehru notably supported Eisenhower's decision to include as many participants as possible to the conference. Nehru also convinced Nasser to not boycott the conference and to send one representative along with Krishna Menon, the Indian representative to the London Conference. ${ }^{45}$

In spite of mediating efforts during the London conference, India did not manage to broker an agreement between the various parties. Nehru was concerned by the risk of escalation following the refusal of European countries to further negotiate after the American proposal was rejected by Egypt. Nehru sent out a message to the Secretary of State John Foster Dulles asking the US to exercise influence to stop British troops from landing in Egypt. Dulles replied stating that 'while the US would not support any disregard of Egypt's rights, it was not clear what precisely these rights were'. ${ }^{46}$ Because the Suez Canal was deemed to be of 'vital importance' to India, Nehru continued to push for a 'peaceful negotiated settlement'. 47

Nehru therefore continued to urge Eisenhower and Eden to consider the Egyptian proposals. The Foreign Ministers of Britain, France and Egypt initiated private talks in New York, at which Krishna Menon was present in a mediatory role. $^{48}$ India was optimistic about a peaceful settlement until Israel launched a sudden military attack on Egypt on October 29, 1956. Two days later, British and French troops took control of the Suez Canal. Along with the US and USSR, India sternly criticised the Anglo-French-Israeli operation. Nehru encouraged the US to intervene. India denounced the Anglo-French ultimatum on the cession of the Suez Canal as a 'flagrant violation of the UN Charter'. ${ }^{49}$ In a letter sent to Dulles, Nehru called the Israeli military operation as a 'clear, naked aggression' and argued that 'the whole future of the relations between Europe and Asia hangs in the balance'. 50 Arthur Lall, India's ambassador to the UN, also urged the American Ambassador to the UN Henry Cabot Lodge to stop the British-French-Israeli action against Egypt. ${ }^{51}$

India's priority was to put an end to a conflict which closed the access to the Suez Canal. India backed the UNGA's efforts in a Special Emergency Session to obtain an immediate ceasefire by all parties and the withdrawal of troops behind the armistice line. On November 2, 1956, India supported a US-sponsored resolution at the UNGA that urged immediate ceasefire and asked all sides to withdraw behind the armistice lines. This proposal came to be referred to as 'the Eisenhower-Nehru formula', and Eisenhower was keen to quickly meet Nehru, 'just the two of them because he thought they came closer to commanding the respect of the world'. ${ }^{2}$ India also agreed to contribute along with 10 other countries to the UN Emergency Force (UNEF) on the condition that Egypt would agree to have such forces based on the 1949 demarcation line separating Egypt from Israel. 
India's involvement in the Suez crisis and the subsequent deployment of the UNEF was driven by an ambition to play an active mediating role between the European powers (France and the UK), the great powers (the US and USSR) and Egypt. Nehru and Eisenhower exchanged sustained correspondence during the crisis, leading to a convergence of interests and a joint condemnation of the Israeli military attack against Egypt. ${ }^{53}$

However, the Suez events and the condemnation of the use of military force were one of the rare instances where Arab, US, Soviet and Indian positions aligned. While the US gradually moved closer to Israel in the following years, Nehru and India broke with the earlier position which had always left open the possibility of diplomatic exchanges. After 1956, the establishment of diplomatic ties was explicitly discarded as it was perceived as potentially hurting India's relations with Arab states and complicated India's potential role as a mediator in the region. As a result, India and the US would stand on opposite sides during the 1967 and 1973 conflicts, with New Delhi unconditionally supporting Egypt and Syria and Washington standing behind Israel.

However, in spite of this decision to defer the development of diplomatic relations, Nehru still met with Israeli diplomats such as Abba Eban, Israel's ambassador to the US, in Washington in December 1956. In a meeting organised by the American diplomat Chester Bowles, Nehru also met with Nahum Goldmann, the president of the Jewish World Congress in 1957. Goldmann did not succeed in convincing Nehru of the necessity of having diplomatic relations with Israel. He reportedly judged Nehru's attitude towards Israel to be 'ambivalent'. ${ }^{54}$ The US back channel of communication between Indian and Israeli officials was discontinued both because of the personal decisions and dispositions of Nehru's successors, Lal Bahadur Shastri and Indira Gandhi, but also because of international alignment policies as India was drawn closer to the USSR following the signing of the Indo-Soviet Treaty of Peace, Friendship and Cooperation in 1971. The US would not play an indirect influence on India-Israel relations until the 1980s.

\section{4-1992: US efforts in facilitating the India-Israel rapprochement}

As the Cold War was waning in the 1980s, Rajiv Gandhi revived the US-based diplomatic channels that his grandfather had previously built on to discuss with Israeli authorities. The Rajiv Gandhi government was also trying to find solutions to improve India's relations with the US, and especially economic ties. Bilateral relations had deteriorated since the Soviet invasion of Afghanistan and the subsequent US military aid given to Pakistan. Another negative development was the increasing criticism of India's 'discriminatory' treatment of Israel coming from the Jewish community in the US, and particularly from the influential ADL. ${ }^{55}$ In May 1987, the ADL published a report condemning India's discriminatory behaviour vis-à-vis Israel. The report highlighted the fact that India had refused to grant visas to Israeli citizens since the mid-1960s and quoted numerous statements hostile to Israel. The report explicitly recommended the imposition of US sanctions on India.

Consequently, the Indian Government became conscious that efforts should be made to prevent pro-Israel American organisations from being obstacles to renewed diplomatic efforts to engage the US. Certain steps were taken by Rajiv Gandhi's government to amend ties with Israel, even before the publication of the ADL report. A few days before the 1985 UNGA annual session, Israel bombarded the Palestine 
Liberation Organisation (PLO) headquarters in Tunis. Rajiv Gandhi condemned the attack and expressed his concern for the safety of Yasser Arafat. ${ }^{56}$ At the UN, India's Minister of External Affairs Bali Ram Bhagat also criticised Israel's 'aggressive and expansionist policies' and called the air raid a 'threat to peace and security' ${ }^{57}$ At first glance, this position seemed in line with India's traditional support of the Arabs and Palestinians against Israel. However, the response in October 1985 was different. In reaction to the raid, 18 Arab states sponsored a UNGA resolution calling for the expulsion of Israel from the UN. Breaking with its traditional support for Arab-backed resolutions, this time India decided to abstain. ${ }^{58}$ In fact, Rajiv Gandhi even met with Israel's Prime Minister Shimon Peres during the 40th UNGA session. This was the first public meeting between two sitting prime ministers of the two countries. As another indication of change, India also decided to relax the visa restrictions for Israeli citizens. For instance, the Rajiv Gandhi government allowed an Israeli tennis team to play against the Indian team in New Delhi for the Davis Cup Tournament in July $1987 . .^{59}$

Rajiv Gandhi had also seemingly realised the influence of pro-Israel organisations and of specific personalities in Congress like Stephen J. Solarz on US policy in that region. ${ }^{60}$ Solarz was a US Congressional Representative from New York. In the 1980s, he chaired the Asian and Pacific Affairs Subcommittee of the House Foreign Affairs Committee. In the House, Solarz represented a district that had one of the country's largest Jewish populations, and he had been a long-time supporter of Israel. He also had an interest in India, and was instrumental in setting up the South Asia Bureau in the US Department of State. ${ }^{61}$ Rajiv Gandhi therefore organised a meeting with Solarz and representatives of various American Jewish organisations in June 1988 in New York. ${ }^{62}$ At the meeting in Rajiv Gandhi's hotel suite, in addition to Solarz the Chairman of the Conference of Presidents of Major Jewish Organisations (and former President of the American Jewish Committee), Morris Abram, the Conference's Executive Vice Chairman Malcolm Hoenlein, the President of the American Jewish Congress Robert Lifton, the Executive Director of the ADL Abe Foxman, and the Executive Director of the American Jewish Committee Ira Silverman, were present. ${ }^{63}$ Gandhi reportedly stated that he wanted to improve economic and political ties with the US. The Jewish organisations encouraged the Indian Prime Minister to change India's policy towards Israel and its citizens, notably on the question of visa restrictions. ${ }^{64}$ They also asked India to pressure the Palestinians to renounce their call for the destruction of Israel and to follow the Egyptian example. ${ }^{65}$ Some Israeli media later suggested that Prime Minister Rajiv Gandhi had pledged during the meeting to upgrade official ties with Israel. ${ }^{66}$

Soon after these discussions, India allowed an Israeli diplomat to be stationed in Bombay (now Mumbai) as vice-consul. This was an important diplomatic move: since the expulsion of the Israeli consul in Bombay by Indira Gandhi in 1982, India had regularly refused requests to replace the position. ${ }^{67}$ In addition, a delegation of the ADL and Congressman Solarz visited New Delhi in 1989. Two of the members of this delegation had been signatories of the 1987 ADL report. The delegation met the Minister of External Affairs Narasimha Rao, Foreign Secretary Alfred Gonsalves and the MEA's Joint Secretary to the Prime Minister P. K. Singh. ${ }^{68}$ One report stated that the delegation of the ADL lobbied in favour of improved Indo-Israeli relations but was notified that change would not be imminent. ${ }^{69}$ Following the meeting, there was another diplomatic gesture towards Israel with the formal extension of the Israeli 
consulate's jurisdiction by the Government of India to the southern state of Kerala which had had a historical and relatively significant Jewish population. ${ }^{70}$

However, in spite of these discussions with pro-Israel organisations and a number of important steps in the direction of change, the Rajiv Gandhi government was unable to bring about a complete reversal of India's foreign policy towards Israel. Instead, in November 1988, India became one of the first non-Arab countries to recognise the newly proclaimed state of Palestine. Domestic political and electoral constraints and regional developments, like the Palestinian Intifada of 1987, restricted any further rapprochement with Israel. US influence on India's Israel policy further increased in the early 1990s, especially in the aftermath of the Gulf War. India's shift of position regarding Iraq and its acceptance to let US military planes refuel at Indian airports was a first important signal that India had to come to terms with the increased American presence in the West Asian region.

The domestic economic crisis in India in 1991 and the disappearance of India's traditional Soviet partner also made New Delhi more dependent on US economic support. In June 1991, Prime Minister Rao inherited an important economic crisis from his predecessor. The crisis was an opportunity for a traditionally self-reliant India to liberalise and to open its economy to the world. With his Finance Minister Manmohan Singh, Rao fundamentally changed India's economic policies. Rao notably sought investments and loans from international institutions such as the International Monetary Fund (IMF) and the World Bank, as well as from the US. ${ }^{71}$ The objective for Rao and Singh was to neutralise all obstacles in Washington to the urgent loans India needed. As Minister of External Affairs in 1988, Narasimha Rao had also been involved in discussions with Solarz and American Jewish organisations and was therefore conscious that the lack of relations with Israel precluded a better understanding with the US whose financial support was essential for India's economic recovery.

Consequently, India first joined the US-backed move to revoke the UNGA Resolution 3379 equating Zionism with racism in December 1991. In the second week of January 1992, the Director General of the Israeli Ministry of Foreign Affairs Joseph Hadass met with the Deputy Chief of the Mission of the Indian Embassy in Washington Lalit Mansingh. Reportedly, Hadass made it clear to Mansingh that it was up for India to take the initiative of establishing diplomatic relations if it wanted to be invited to participate in the nascent West Asian peace process. ${ }^{72}$ Narasimha Rao then announced the establishment of diplomatic relations with Israel on the eve of a visit to the UN in New York where he would meet with US President George H. W. Bush. Following the announcement, Congressman Stephen Solarz also issued a press release welcoming the new diplomatic development. ${ }^{73}$

\section{2-2016: the defence equation}

Following the establishment of diplomatic relations between India and Israel in January 1992, defence ties, and especially arms sales from Israel to India, became a major component of this emerging partnership. The US role in the development of defence relations has, however, been neither direct nor systematic. In fact, the Bill Clinton administration initially opposed Israeli defence sales to India because of technology transfer regimes and the embargo linked to the Indian nuclear tests of 1998. This situation evolved under the George W. Bush administration which then openly encouraged defence cooperation between two partners it was openly trying to 
enrol in its global War on Terror. The contemporary situation is uncertain as both American and Israeli defence industries are now openly competing for access to the growing Indian market.

There were international obstacles to defence technology transfer in the 1990s. Some of the Israeli technology which had been co-produced with the US could not be shared without a prior approval from Washington. The US had, for instance, previously blocked the Israeli transfer of Lavi, patriot missile and Phalcon technologies to China. ${ }^{74}$ Nevertheless, the US first indirectly helped Israeli defence industries gain a foothold on the Indian market following the Indian and Pakistani nuclear tests of May 1998. In the immediate days following the tests, the US placed both India and Pakistan under economic sanctions. ${ }^{75}$ The sanctions included banning US economic assistance and the export of defence material and technologies.

Unlike the US, and even Russia, Israel did not condemn the nuclear tests and did not join the weapons embargo against New Delhi. Instead, just a few days after the tests, a delegation from Israeli Aerospace Industries (IAI) visited India to accelerate the sale of Israeli-made Unmanned Aerial Vehicles (UAVs) ${ }^{76}$ A few weeks later, the IAI also finalised a large-scale deal to sell India advanced electronic equipment for warplanes. The fact that this equipment was solely developed and manufactured in Israel and contained no American technology helped circumvent the existing sanctions, but the US nevertheless opposed the deal by arguing that it violated international arms control treaties. In spite of this criticism, Israel honoured the deal that had been signed in $1996 .{ }^{77}$ In fact, Israel also assured India that all contracts and joint ventures which had been negotiated prior to the tests would be respected. ${ }^{78}$

The initial American apprehensions were, however, put aside in the early 2000s. At the time, the Bharatiya Janata Party (BJP) government was negotiating with Israel the $\$ 1.1$ billion purchase of the Phalcon Airborne Warning and Control System (AWACS). This deal was a game-changer for two main reasons. First, the Phalcon system brought a new qualitative edge to Indo-Israeli defence operations. Second, the deal marked the evolution of the US position on technology transfer between Israel and India. In 2000, under intense pressure from the Clinton administration, Israel had been forced to cancel the sale of the Phalcon radar system to China despite the loss of a billion-dollar contract. ${ }^{79}$ Weary of the Chinese precedent, India and Israel coordinated their efforts with high-ranking US officials during the negotiations. After four years, Washington finally authorised the Phalcon sale in $2003 .{ }^{80}$

The success of the Phalcon deal was also the result of a new strategy of political lobbying from the BJP in Washington. Since Rajiv Gandhi's tenure, Indian policymakers, including in the BJP government, had realised that the engagement of Jewish organisations based in the US was necessary to mobilise American support for defence relations with Israel. Since 1992, India and Israel had been regularly discussing defence exchanges but India could only purchase weapons and technologies which were exclusively Israeli-made. There were institutional and legal obstacles to the purchase of the Phalcon AWACS, and of ballistic missile defence systems, as some of the technology originated from the US. India was still targeted by US technological embargoes and sanctions which had been imposed after the nuclear tests of 1974 and 1998. Consequently, India actively engaged American Jewish organisations to gain the approval of the US administration. Indian-American organisations like the US-India Political Action Committee have also both emulated and established institutional links with the American-Israel Political Action Committee (AIPAC), and the AJC to push for a rapprochement between India and the US. ${ }^{81}$ 
India's National Security Adviser Brajesh Mishra's visit to the US and speech to the AJC in May 2003 must be seen within this objective of improving relations with both Israel and the US. In his speech, Mishra formulated the idea of a tripartite axis between the US, Israel and India. Noting that all these countries were democracies which shared a 'common vision of pluralism tolerance and equal opportunities', he argued that stronger relations between the three countries had a 'natural logic' ${ }^{82} \mathrm{He}$ added that the three democracies shared similar security threats and should form a 'viable alliance' to combat the common threat of 'global terrorism' ${ }^{83}$ While there has been no attempt to follow up with concrete initiatives on these statements, this appearance of an ideological rapprochement enabled further Indo-Israeli defence cooperation without any explicit US opposition.

For instance, in other high-technology niche areas such as missile defence where India had failed to build robust indigenous capabilities, Israel offered key equipment and expertise, such as the Barak-I point-defence systems that India bought in $2001 .^{84}$ Israel also proved to be an indirect access to US defence technology (such as subelements of the Arrow system like Green Pine Radar). ${ }^{85}$ However, the burgeoning defence partnership between India and Israel has also now created problems for some US defence industries which are increasingly targeting Indian defence contracts in niche markets. While Israel stands only in fourth position as arms supplier to India behind Russia, the US and France, and that Israel and the US will not be directly contesting major platforms like combat aircrafts, US and Israeli firms have competed over specific tenders.

A recent example is symptomatic of the possible tensions related to the growing competition between India and Israel in specific sectors. India originally considered buying the US-made 'Javelin' Anti-Tank Guided Missiles (ATGM). Negotiations were 'nearly completed' for the two countries to jointly develop the ATGM by late 2016. ${ }^{86}$ However, the negotiations ultimately stalled because of Washington's reluctance to share technology with India and to not allow India to then indigenously manufacture the 'tank killer' missiles. In parallel, India also discussed with Israel the supply of the 'Spike' third-generation ATGMs. India is reportedly in the final stages of inking a deal with Israel's Rafael Advanced Defence Systems for the purchase of the ATGMs. ${ }^{87}$ This development has confirmed Israel's flexibility in technology transfer and its imposition of very minimal conditions in its dealings with India compared to the US.

Over the last two decades, Israeli defence industries have proven to be appealing partners for India because of their willingness to transfer technology and to engage in joint ventures, production and research and development in high-technology military equipment. ${ }^{88}$ By contrast, India-US defence ties have historically been hindered by suspicion in developing jointly defence platforms. ${ }^{89}$ In spite of the signing of the Defence Trade and Technology Initiative (DTTI), and discussions of collaboration on developing India's next generation aircraft carrier, India remains wary of the reliability of the US as a defence partner given past embargoes. American defence industries on the other hand are still working on how to comply with India's defence offset policy.

\section{Conclusion}

This article's main objective was to demonstrate that, contrary to popular and even academic belief in India, the US factor in India-Israel relations has never been consistent and has evolved over time depending on the personalities, political 
constellations in power in India and the regional developments in West Asia. While most observers of India-US relations note that one of the foundational disagreements between these powers was American support for Pakistan, few bring up the early disputes over the creation of the state of Israel. Rarely is it also evoked that India and the US coordinated their condemnation of Israeli actions during the Suez crisis of 1956.

Often overlooked by state-centric approaches, another important finding is that non-state and sub-state actors such as specific political personalities like Congressmen Celler and Solarz, as well as pro-Israel interest groups based in the US, have played an important role in shaping the nature of India-Israel ties. The US government has never consistently or directly attempted to pressure India to change its policy towards Israel. In fact, it was the opening of an indirect channel of communication of Rajiv Gandhi with US-based Jewish organisations through the mediation and support of Congressman Solarz in the 1980s which paved the way for the ultimate establishment of diplomatic relations in 1992.

Furthermore, while India, Israel and US interests seem to have converged at some junctures in history like in 2003, their policies and strategies rarely align. As mentioned previously, India and the US stood together against Israeli actions and interests in 1956. As detailed in the last section, the US has promoted but also directly opposed Israeli arms sales to India because of concerns of technology transfer but also due to increasing competition concerns. Another important development to monitor is whether Israel's 'clear and purposeful' engagement of Asian partners like China and India is not also a response to a more lukewarm or uncertain US support to its policies over the last decade. ${ }^{90}$ Whether it has been driven by President Barack Obama's explicit criticism of Israel's settlement policies or President Donald Trump's varying rhetoric on the two-state solution, it seems clear that Prime Minister Benyamin Netanyahu's government has been hedging towards consolidating alternative partnerships in Asia, ${ }^{91}$ and especially with India, which remains its main market for defence exports. It remains to be seen, however, if closer Israel-India ties develop at the expense of the third party in this difficult strategic equation.

\section{Disclosure statement}

No potential conflict of interest was reported by the author.

\section{Notes}

1. For more on the historical background of the relationship, see Nicolas Blarel, The Evolution of India's Israel Policy: Continuity, Change, and Compromise since 1922, Oxford University Press, New Delhi, 2015; P. R. Kumaraswamy, India's Israel Policy, Columbia University Press, New York, 2010.

2. Michael Brecher, 'Israel and Afro-Asia', International Journal, 16, 1961, pp. 107-137; Michael Brecher, The New States of Asia; A Political Analysis, Oxford University Press, London, 1963, pp. 129-130; Michael Brecher, India and World Politics: Krishna Menon's View of the World, Oxford University Press, Oxford, 1968; P. R. Kumaraswamy, no. 1; B. R. Nanda (ed.), Indian Foreign Policy: The Nehru Years, University Press of Hawaii, Honolulu,1976; Gideon Shimoni, Gandhi, Satyagraha and the Jews: A formative Factor in India's Policy towards Israel, Leonard Davis Institute for International Relations, Hebrew University of Jerusalem, Jerusalem, 1977. 
3. Stephen P. Cohen, India: Emerging Power, Oxford University Press, New Delhi, 2001; P. R. Kumaraswamy, 'Israel-India Relations: Seeking Balance and Realism', in Efraim Karsh (ed.), Israel: The First Hundred Years: Israel in the International Arena, Frank Cass, London, 2004; C. Raja Mohan, Crossing the Rubicon: The Shaping of India's Foreign Policy, Penguin, London, 2005.

4. Nicolas Blarel, 'Indo-Israeli Relations: Emergence of a Strategic Partnership', in Sumit Ganguly (ed.), India's Foreign Policy: Retrospect and Prospect, Oxford University Press, New Delhi, 2009, pp. 143-161.

5. Nicolas Blarel, no. 1, Chapter 1.

6. Ariel Glucklich, 'Brahmins and Pharisees: The Roots of India's Anti-Zionism', Midstream, 34, 1988, pp. 12-15.

7. Michael Brecher, 'Israel and China: An Historic "Missed Opportunity"', in Michael Curtis and Susan Aurelia Gitelson (eds), Israel in the Third World, Transaction Books, New Brunswick, 1976.

8. P. R. Kumaraswamy, no. 1, pp. 31-35; Gideon Shimoni, no. 2.

9. Joseph Schechtman, 'India and Israel', Midstream, 12, 1966, pp. 48-71.

10. Gideon Shimoni, no. 2, p. 49.

11. Jawaharlal Nehru, Glimpses of World History, Penguin, New Delhi, 2004 [1934], p. 891.

12. Shimoni, no. 2, pp. 39, 51.

13. Ibid., pp. $58-59$.

14. Mohandas Karamchand Gandhi, The Collected Works of Mahatma Gandhi, vol. 84, Publications Division, New Delhi, 2000, pp. 440-441.

15. Cited in P. R. Kumaraswamy, no. 1, p. 87.

16. Sarvepalli Gopal (ed.), Selected Works of Jawaharlal Nehru, Series II, vol. 2, Orient Longman, New Delhi, 1988, p. 494.

17. Itzhak Gerberg, The Changing Nature of Israeli-Indian Relations: 1948-2005, University of South Africa, Pretoria, 2008, p. 193.

18. Sarvepalli Gopal, no. 16, p. 497.

19. Ibid., pp. 474-475.

20. United Nations Special Committee on Palestine (UNSCOP), Report to the General Assembly, vol. 1, ch. IV, United Nations, New York, 1947, p. 44.

21. Gopal Krishan and Sarabjit Sharma, India and Israel: Towards Strategic Partnership, Authors Press, New Delhi, 2007, pp. 122-123.

22. UNSCOP, Report to the General Assembly, Vol. 2, A/364, Add. 1, United Nations, New York, 1947, p. 44.

23. P. R. Kumaraswamy, no. 1, p. 64; Gideon Shimoni, no. 2, p. 57.

24. Nicolas Blarel, no. 1, p. 88.

25. Ibid., p. 94.

26. Benny Morris, 1948: A History of the First Arab-Israeli War, Yale University Press, New Haven, 2008, p. 56.

27. P. R. Kumaraswamy, no. 1, p. 104.

28. Itzhak Gerberg, no. 17, pp. 194-195; Prithvi Ram Mudiam, India and the Middle East, British Academic Press, London, 1994, pp. 144-147.

29. Michael J. Devine (ed.) Harry S. Truman, The State of Israel, and the Quest for Peace in the Middle East, Truman State University Press, Kirksville, 2009; Evan M. Wilson, Decision on Palestine: How the United States Came to Recognize Israel, Hoover Press, Stanford, 1979.

30. G. Parthasarathi (ed.), Jawaharlal Nehru, Letters to Chief Ministers, vol. 1: 1947-1949, Oxford University Press, Delhi, 1987, pp. 127-128.

31. P. R. Kumaraswamy, no. 1, p. 109.

32. Paul McGarr, The Cold War in South Asia: Britain, the United States and the Indian Subcontinent, 1945-1965, Cambridge University Press, New York, 2013, ch. 1.

33. Itzhak Gerberg, no. 17, pp. 77, 209-210, 215.

34. Shimon Avimor (ed.), Relations between Israel and Asian and African States: A Guide to Selected Documentation, Maor-Wallach Press Ltd, Jerusalem, 1991, p. 172.

35. P. R. Kumaraswamy, no. 1, p. 112.

36. Shimon Avimor (ed.), no. 33, p. 172; Itzhak Gerberg, no. 17, pp. 230-231.

37. Itzhak Gerberg, no. 17, pp. 230-231.

38. Cited in P. R. Kumaraswamy, no. 1, p. 119.

39. Paul McGarr, no. 31, pp. 16-25. 
40. Donald Eugene Smith, South Asian Politics and Religion, Princeton University Press, Princeton, 1966, p. 440.

41. The Canal Corporation was an Egyptian company subject to Egyptian law, and the nationalisation was therefore considered to be within the competence of Egyptian law. See Lok Sabha Debates, vol. 7, pt 2, Lok Sabha Secretariat, New Delhi, August 8, 1956, pp. 2536-2544.

42. Quote by Krishna Menon at London Conference, in Foreign Relations of the United States, 1955-1957, Suez Crisis, July 26-December 31, 1956, vol. 16, US Government Printing Office, Washington,1956, pp. 159-178.

43. Lok Sabha Debates, no. 40.

44. Ibid.

45. Swapna Kona Nayudu, The Nehru Years: Indian Non-Alignment as the Critique, Discourse and Practice of Security (1947-1964), Doctoral Thesis, King's College London, 2015, pp. 135-136.

46. Quoted in ibid., p. 141.

47. Lok Sabha Debates, vol. 8, pt 2, September 13, 1956, pp. 6963-6968.

48. Swapna Kona Nayudu, no. 44, p. 143.

49. Foreign Affairs Record, vol. 2, no. 10, Ministry of External Affairs, October 10, 1956.

50. M. S. Rajan, India in World Affairs, 1954-1956, Asia Publishing House, London, 1964, p. 151.

51. Ibid., p. 144.

52. Ibid., p. 145.

53. Dwight D. Eisenhower, The White House Years: Mandate for Change 1953-56, Doubleday, Garden City, 1963, p. 83.

54. Nahum Goldmann, Sixty Years of Jewish Life, Holt, Rinehart and Winston, New York, 1969, p. 310.

55. India's Campaign against Israel, Anti-Defamation League of BnaiBrith, New York, 1987.

56. Annual Report, External Publicity Division of the Ministry of External Affairs, New Delhi, 1985-1986, p. 20.

57. The Times of India, October 3, 1985.

58. Richard E. Ward, India's Pro-Arab Policy: A Study in Continuity, Praeger, New York, 1992, p. 124.

59. P. R. Kumaraswamy, 'India, Israel and the Davis Cup Tie 1987', Journal of Indo-Judaic Studies, 5, 2002, pp. 29-39.

60. It is important to note here that I am referring to perceptions of the Indian Government of the influence of Jewish-American organisations in the US context on US foreign policy which led to the engagement of these organisations. The US political system is widely regarded as very favourable to interest groups, and particularly ethnic interest groups' influence, as argued by Allan J. Cigler and Burdett A. Loomis, Interest Group Politics, CQ Press, Washington, 2007; Patrick Haney, 'The Role of Ethnic Interest Groups in US Foreign Policy: The Case of the Cuban American National Foundation', International Studies Quarterly, 43(2), 1999, pp. 341-361; Henriette M. Rytz, Ethnic Interest Groups in US Foreign Policy-Making: A CubanAmerican Story of Success and Failure, Palgrave Macmillan, New York, 2013; Tony Smith, Foreign Attachments: The Power of Ethnic Groups in the Making of American Foreign Policy, Harvard University Press, Cambridge, 2000; and John J. Mearsheimer and Stephen M. Walt, The Israel Lobby and US Foreign Policy, Farrar, Straus and Giroux, New York, 2007. However, this scholarship has generally found that ethnic interest groups' influence over US foreign policy has not been consistent over time. Even the most influential coalition of proIsrael organisations, loosely referred to as the 'Jewish Lobby' by Mearsheimer and Walt, has not always been successful at shaping US policy towards the Middle East. The sale of AWACS aircraft to Saudi Arabia in the 1980s or the Iran nuclear deal of 2015 were pushed through by two different US administrations, against the will of the American Israel Public Affairs Committee (AIPAC).

61. Itzhak Gerberg, no. 17, p. 246.

62. P. R. Kumaraswamy, no. 57.

63. Robert Lifton, An Entrepreneur's Journey: Stories from a Life in Business and Personal Diplomacy, Author House, Bloomington, 2012, pp. 255-256.

64. Los Angeles Times, June 10, 1988.

65. Robert Lifton, no. 61, p. 256. 
66. Los Angeles Times, June 10, 1988.

67. P. R. Kumaraswamy, no. 1, p. 227.

68. The Hindu, January 6, 1988.

69. Richard E. Ward, India's Pro-Arab Policy: A Study in Continuity, Praeger, New York, 1992, pp. $128-129$.

70. Itzhak Gerberg, no. 17, pp. 113-114.

71. 'Economic Crisis Forcing Once Self-Reliant India to Seek Aid', New York Times, June 29, 1991.

72. Interview with Ambassador Lalit Mansingh, October 12, 2011, New Delhi.

73. Itzhak Gerberg, no. 17, p. 336.

74. Yitzhak Shichor, 'Israel's Military Transfers to China and Taiwan', Survival, 40, 1998, pp. 68-91.

75. 'Clinton Imposes Full Sanctions on India', Business Standard, May 14, 1998.

76. International Herald Tribune, June 10, 1998.

77. Farah Naaz, 'Indo-Israel Military Cooperation', Strategic Analysis, 24, 2000, pp. 969-985.

78. The Statesman, August 20, 1998.

79. P. R. Kumaraswamy, 'Israel-China Relations and the Phalcon Controversy', Middle East Policy, 12, 2005, pp. 93-103.

80. 'US Approves Israeli Phalcon Sale to India', Indian Express, May 23, 2003.

81. For more on the Indian lobby, see Jason A. Kirk, 'Indian-Americans and the US-India Nuclear Agreement: Consolidation of an Ethnic Lobby?', Foreign Policy Analysis, 4 (3), 2008, pp. 275-300.

82. NSA Brajesh Mishra's speech at the American Jewish Committee dinner, May 5, 2003, at http:/www.mea.gov.in/Speeches-Statements.htm?dtl/4526/Address+by+Shri+Brajesh+Mishra + National + Security + Advisor + at + the + American + Jewish + Committee + Annual + Dinner (Accessed April 10, 2017).

83. Ibid.

84. Shishir Gupta, 'India to Buy Missile Defense Systems from Israel', Hindustan Times, February 11, 2001.

85. Ninan Koshy, 'US plays Matchmaker to India, Israel', The Asia Times, June 10, 2003.

86. Vivek Raghuvanshi, 'US, India Said to be Nearing Javelin Co-Production Agreement', DefenseNews.com, September 21, 2016, at http://www.defensenews.com/articles/us-indiasaid-to-be-nearing-javelin-co-production-agreement (Accessed April 10, 2017).

87. Rahul Singh, 'India, Israel seal \$2 billion missile deals: What it means for New Delhi?', Hindustan Times, April 7, 2017.

88. Elizabeth Roche, 'India Calls for Broadening of Defence Ties with Israel', Livemint, November 16, 2016.

89. Seema Sirohi, 'The US Defence Secretary's Visit to India Is about One Thing-Technology', Quartz India, June 3, 2015, at https:/qz.com/418514/the-us-defence-secretarys-visit-to-indiais-about-one-thing-technology/ (Accessed April 10, 2017).

90. Herb Keinon, 'Israel Is Clearly Pivoting to Asia, Netanyahu Announces in Singapore', Jerusalem Post, February 21, 2017.

91. Leslie Shaffer, 'Israeli Prime Minister Netanyahu: We Are Pivoting toward Asia', CNBC, February 20, 2017, at http:/www.cnbc.com/2017/02/20/israel-prime-minister-netanyahu-weare-pivoting-toward-asia.html (Accessed April 10, 2017). 